\title{
The Circadian Clock, the Immune System, and Viral Infections: The Intricate Relationship Between Biological Time and Host-Virus Interaction
}

\author{
Gianluigi Mazzoccoli ${ }^{1, *}$, Manlio Vinciguerra ${ }^{2}$, , Annalucia Carbone ${ }^{1}$ and \\ Angela Relógio ${ }^{3,4, *(1)}$ \\ 1 Department of Medical Sciences and Chronobiology Laboratory, Fondazione IRCCS “Casa Sollievo della \\ Sofferenza”, 71013 San Giovanni Rotondo (FG), Italy; annalucia.carbone@gmail.com \\ 2 Epigenetics, Metabolism and Aging (EMA) research group, International Clinical Research Center, St. Anne's \\ University Hospital, 65691 Brno, Czech Republic; manlio.vinciguerra@fnusa.cz \\ 3 Institute for Theoretical Biology (ITB), Charité-Universitätsmedizin Berlin, corporate member of Freie \\ Universität Berlin, Humboldt-Universität zu Berlin and Berlin Institute of Health, 10117 Berlin, Germany \\ 4 Medical Department of Hematology, Oncology, and Tumor Immunology, and Molekulares \\ Krebsforschungszentrum (MKFZ), Charité-Universitätsmedizin Berlin, corporate member of Freie \\ Universität Berlin, Humboldt-Universität zu Berlin and Berlin Institute of Health, 10117 Berlin, Germany \\ * Correspondence: g.mazzoccoli@operapadrepio.it (G.M.); angela.relogio@charite.de (A.R.)
}

Received: 9 December 2019; Accepted: 22 January 2020; Published: 27 January 2020

\begin{abstract}
Living beings spend their lives and carry out their daily activities interacting with environmental situations that present space-time variations and that involve contact with other life forms, which may behave as commensals or as invaders and/or parasites. The characteristics of the environment, as well as the processes that support the maintenance of life and that characterize the execution of activities of daily life generally present periodic variations, which are mostly synchronized with the light-dark cycle determined by Earth's rotation on its axis. These rhythms with 24-h periodicity, defined as circadian, influence events linked to the interaction between hosts and hosted microorganisms and can dramatically determine the outcome of this interplay. As for the various pathological conditions resulting from host-microorganism interactions, a particularly interesting scenario concerns infections by viruses. When a viral agent enters the body, it alters the biological processes of the infected cells in order to favour its replication and to spread to various tissues. Though our knowledge concerning the mutual influence between the biological clock and viruses is still limited, recent studies start to unravel interesting aspects of the clock-virus molecular interplay. Three different aspects of this interplay are addressed in this mini-review and include the circadian regulation of both innate and adaptive immune systems, the impact of the biological clock on viral infection itself, and finally the putative perturbations that the virus may confer to the clock leading to its deregulation.
\end{abstract}

Keywords: clock; circadian rhythms; virus; host; immune system

\section{Introduction}

Rotation of the planet Earth around its axis generates rhythmic day/night alternations with a period of approximately $24 \mathrm{~h}$ (circadian). The term circadian originates from the Latin circa dies, "approximately one day", more or less the time length of day/night or light/dark cycles. Circadian rhythms, generated by the endogenous circadian clock, allow living beings to anticipate environmental daily changes and provide an evolutionary advantage that favours survival despite strong selective pressure. The circadian clock is evolutionary conserved and thought to be roughly 2.5 billion years 
old, tracing back to cyanobacteria, which started releasing vast amounts of oxygen during the Great Oxidation Event, prior (700 million years) to the divergence of plants, animals, and fungal lineages [1-3].

The biological clock is a molecular network which generates oscillations in gene and protein expression that control cellular functioning and allows for the timely separation of biological processes that cannot or should not coexist. These include redox reactions and DNA replication [4], switches in metabolic pathways [5-7], as well as behavioural and physiological rhythms [8]. The endogenously driven rhythms are synchronized by external cues, such as environmental light and temperature, and feeding times $[4,7,9]$ and are resilient to temperature fluctuations within the physiological range $[10,11]$.

\subsection{The Circadian Clock Circuitry}

In mammals, the system driving the generation of internal timing and ultimately the regulation of physiology and behaviour is formed by a hierarchical network of biological oscillators with two hubs in the hypothalamic suprachiasmatic nuclei (SCN) [12]. The SCN clock (main pacemaker) is necessary for the maintenance of 24-h body rhythms [13,14] and can restore [15] or de novo establish circadian rhythms in gene expression when transplanted in genetically arrhythmic mice [16,17]. The circadian circuitry encompasses molecular clocks of the main pacemaker and additional cellular clocks in peripheral tissues [18-20]. These are driven by the SCN through neural and humoral outputs [21] and, together with the main pacemaker, manage circadian timing of physiological processes and behaviour [2,22]. One of the main external synchronizers (or zeitgeber) is light, a strong central pacemaker-tuning cue [23]. Light information is perceived by retinal ganglion cells expressing the photopigment melanopsin and passed on to the SCN through retino-hypothalamic tract fibres [24-27] and to neighbouring and downstream oscillators via neurotransmitters such as glutamate, PACAP, VIP, GRP [25,28,29], VP [30,31], and GABA [32]. Even though the oscillators in the SCN are capable of autonomous ticking, the oscillations become progressively dampened in peripheral oscillators in the absence of SCN-synchronizing signals [33].

\subsection{The Molecular Mechanisms of Biological Ticking}

The molecular clockworks generate rhythmic oscillations through "transcription-translation feedback loops" (TTFL), i.e., core-clock transcription factors positively turn on the expression of genes encoding circadian proteins that subsequently inhibit transcription via negative-feedback loops, with a time delay indispensable for the proper functioning of the biological clock [34]. The TTFL is manoeuvred by several core-clock mRNAs and proteins, including activators (BMAL1, CLOCK, ROR $\alpha$, ROR $\beta$, and ROR $\gamma$ ) and repressors (PER1, PER2, PER3, CRY1, CRY2, REV-ERB $\alpha$, and REV-ERB $\beta$ ), kinases (CKI $\alpha, \mathrm{CKI} \delta$, and $\mathrm{CKI} \varepsilon)$, and phosphatases (PP1 and PP5) that control protein stability and subcellular localization. CLOCK (or its paralogue NPAS2) and BMAL1 (alias ARNTL), as basic helix-loop-helix-PAS (bHLH-PAS) transcription factors [34] heterodimerize and bind to E-boxes in the promoter regions of the genes encoding the period (PER1, PER2, and PER3) and cryptochrome (CRY1 and CRY2) proteins, which upon heterodimerization in the cytoplasm translocate back into the nucleus and repress CLOCK:BMAL1-mediated transcription. Then, ubiquitination-dependent degradation of PER/CRY complexes takes place and a new round of CLOCK:BMAL1-mediated transcription restarts [34].

In addition, the nuclear receptors REV-ERB $\alpha$ and REV-ERB $\beta$ compete with ROR $\alpha, \operatorname{ROR} \beta$, and ROR $\gamma$ at ROR-binding elements (ROREs) in the promoter region of BMAL1 and fine-tune its transcription [34]. The CLOCK:BMAL1 heterodimer activates another auxiliary loop operated by the PAR-bZip transcription factors D-Box Binding PAR BZIP (DBP), Thyrotrophic Embryonic Factor (TEF), and Hepatic Leukemia Factor (HLF); bind to D-box-containing sites within the promoter region of the transcriptional repressor NFIL3 (alias E4BP4); and prompts numerous downstream transcriptional events [34]. 


\subsection{Viruses and Circadian Clock Circuits}

Synchronization with the external environment and anticipation of predictable environmental changes confer competitive advantages to living beings, especially in the wild. Accordingly, in humans experiencing dysregulation of circadian timing, for example, due to shift work or social jet lag, there is increased incidence of various degenerative, inflammatory, metabolic, and neoplastic diseases [35,36]. Besides human health and wellbeing maintenance, a detailed knowledge of the molecular mechanisms operating biological clocks has implications also for the efficacy of treatment strategies for pathological states.

Mounting evidence shows that time-of-day-related treatment schedules and chrono-modulated drug delivery significantly affect both effectiveness and side effects of pharmacological therapy [37-39]. Diseases caused by viruses, rickettsiae, bacteria, fungi, or parasites continue to represent a primary cause of morbidity. Infections by viruses rework the biological processes of infected cells to facilitate replication and spread, and thus the molecular interplay between the mechanisms of the biological clock, immune system, and virus infection can influence disease outcomes (Figure 1).

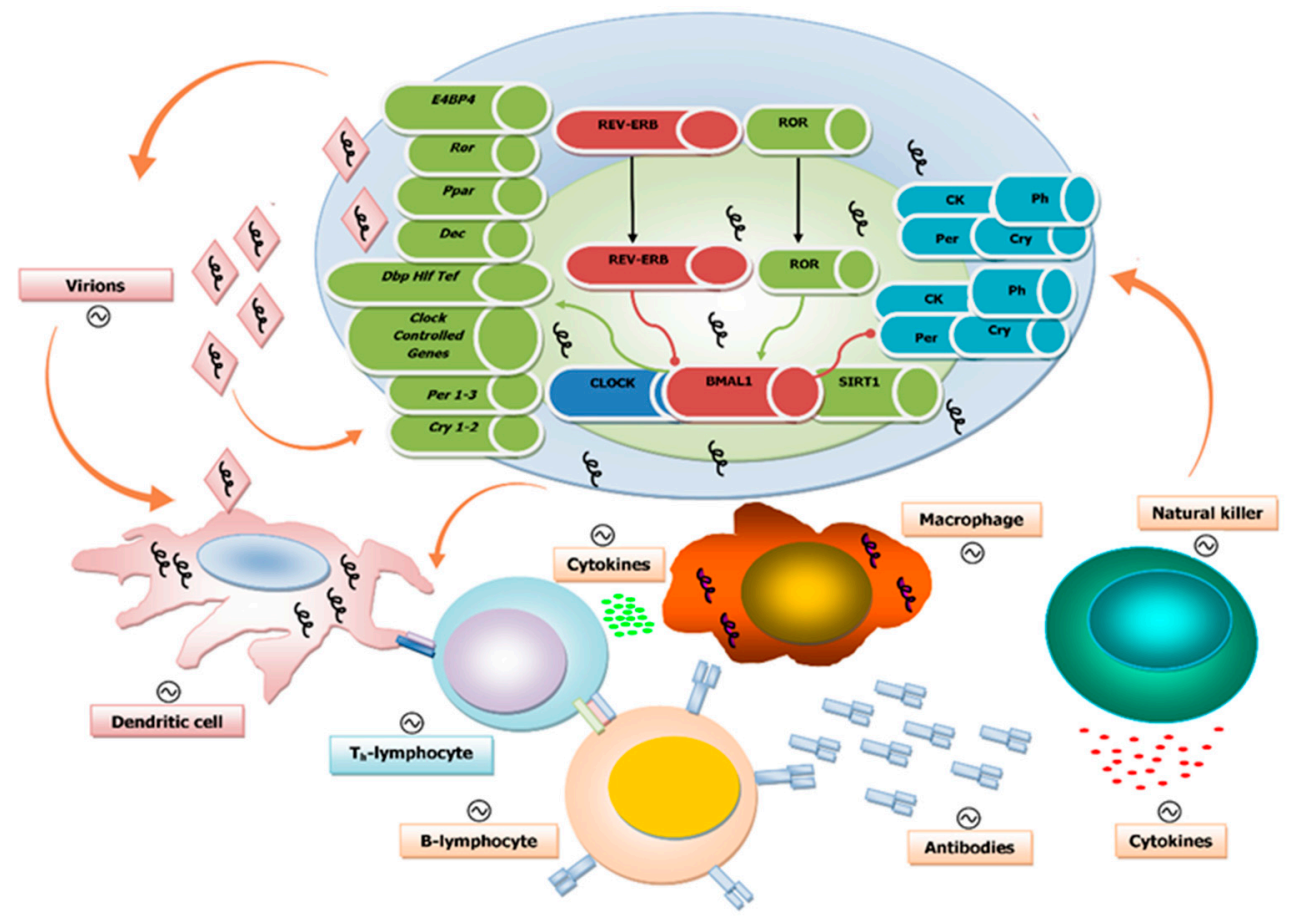

Figure 1. Schematic illustration of the interplay between the biological clock, virus replication, and the immune system at the cellular level: The components of the molecular clockwork are depicted within the cell, with green arrows indicating activation and red arrows indicating inhibition. The presence of viral genomes is indicated by squiggles. Below the cell are elements of the immune response. The orange arrows indicate interactions among virions, biological clocks, and immune competent cells. The interaction of virions and their nucleic acid core with these two players impacts viral replication and rhythmic patterns of host-hosted molecular trade off. The immune system with its innate and adaptive arms provides shielding against viral infections with a number of molecular factors and effectors, such as dendritic cells, T and B cells, macrophages, and natural killer cells. These are engaged to hold up and hinder virus replication and dissemination through the secretion of cytokines and the production of specific antibodies. The components and, ultimately, the complex function of the immune system are rhythmically driven by the biological clock and, in turn, influence the function of the molecular clockwork. Viral particles impact the interplay between immune and circadian systems. 


\subsection{Circadian Regulation of Both Innate and Adaptive Immune Systems}

The circadian regulation of the immune system response allows for its time-dependent success against different pathogens in a rhythmic fashion [40-44]. Immune cells of the innate and adaptive components of the immune system have molecular clockworks managing their rhythmic processes on a 24-h timescale [45-49], such as lymphocyte migration through lymph nodes and lymph in mice [50].

The rhythmic function of the immune system influences the appearance of pathological conditions, for instance, inflammatory lung disease and asthma, which show circadian fluctuations in symptoms and occurrence. In a recent study using both acute and chronic models of virus-induced airway disease (based on the Sendai virus $(\mathrm{SeV})$ ), disturbance of the 24-h periodicity negatively affected development, progression, and exacerbation of asthma [51]. In this study, BMAL1 silencing lead to more pronounced asthma-typical airway changes, which suggests a role for BMAL1 in the regulation of lung-specific antiviral responses and the subsequent development of asthmatic symptoms. This study reinforces the previous findings from Majumdar et al., who reported a role for BMAL1 as a regulator of innate immunity and showed that BMAL1-deficent cells are more susceptible to infection of the RNA viruses RSV (respiratory syncytial virus) and PIV3 (parainfluenza virus type 3) [52].

The efficacy of vaccination is also thought to be under circadian control as suggested by results obtained in mice and human studies. Silver et al. have shown in immunized mice that vaccination at the time of higher TLR9 (Toll-like receptor 9) expression led to enhanced immune response, likely due to the circadian expression pattern of TLR9 [44]. Interestingly, in the same study, PER2-deficient mice did not show the observed time variation of immune response. Likewise, the antibody response to viral challenge in humans was also reported to be time dependent: immunization with hepatitis $\mathrm{A}$ and influenza virus vaccines in the morning led to higher antibody response as compared to afternoon vaccination [53-55].

\subsection{Influence of the Biological Clock on Virus Replication Cycle and Disease}

Cellular and tissue functions exhibit rhythmic fluctuations over the course of $24 \mathrm{~h}$ that impact the susceptibility to or progression of the viral infection. Several core-clock elements have been reported to modulate viral infection. BMAL1 and PER2 are regulators of antiviral immunity, as described in the previous section, and additional roles for PER1 and REV-ERB $\alpha$, as well as melatonin have been highlighted, as described in the following. The seasonal variation of BMAL1 expression, reaching its lowest values in winter, seems to contribute to the high occurrence of respiratory viral diseases in this season since low BMAL1 expression enhances viral disease [56,57]. An effect of the circadian clock in viral infection was also reported for wild-type mice infected with murine herpesvirus 4 at different times of the day. The mice were kept under controlled temperature and lighting environment (12-h light/12-h darkness), and the levels of infection and spread of the virus were evaluated [58]. In mice infected at the beginning of the day, corresponding to the beginning of the resting phase of these nocturnal animals, the viral replication was increased tenfold compared to the values measured in mice infected during the night period, corresponding to the activity phase. In mice lacking BMAL1, the levels of virus replication were independent of the time of day at which the viral infection was performed [58]. The effect of time of infection on virus replication was independent of the immune system, as also confirmed on single cell cultures (embryonic fibroblasts), in which several time-dependent processes (intracellular trafficking, biosynthetic processes, protein synthesis, and chromatin assembly) were involved. The obliteration of cellular circadian rhythms increased the replication of herpes and influenza A viruses, which lost rhythmic fluctuation and remained persistently high [58]. The time of day of herpes simplex virus type 2 (HSV-2) infection impacted the outcome of the pathology in wild-type mice kept under 12-h light and 12-h darkness (LD 12:12), probably due to the circadian rhythmic expression of the HSV-2 receptor in the skin Nectin1. This effect was confirmed in immunodeficient RAG2-knockout mice [59].

Moreover, the core-clock gene PER1 was identified as a negative regulator of HIV-1 transcription and its expression inversely correlated with viral loads, likely in relation to different latencies of the virus in resting CD4+ T-cells [60]. 
Liver infection caused by hepatitis $B$ and $C$ viruses was also reported to be under circadian control. REV-ERB $\alpha$ plays an indirect role in Hepatitis C Virus (HCV) infection by negatively regulating miR122 [61], a microRNA known for its essential role in HCV replication [62]. In addition, PER2 overexpression decreased HCV RNA replication in permissive hepatocyte-derived cells. Interestingly PER2 can influence interferon signalling, which is a known player in regulating both the innate and the adaptive antiviral response and viral replication [46]. Enhanced expression of interferon was also observed as a result of melatonin administration in a mouse model of VEE (Venezuelan equine encephalomyelitis). Melatonin is a well-known component of the circadian system; this hormone is produced with 24-h rhythmicity by the pineal gland and has been associated with improved response against viruses. This study showed that melatonin administration results in decreased mortality upon VEE infection [63]. Melatonin was successfully applied against the respiratory syncytial virus (RSV), a pathogen causing severe disease in children, resulting in increased survival of newborn children with RSV-related respiratory sepsis [64]. In addition, the administration of melatonin in the treatment of individuals who are infected with the Ebola virus was reported to reduce several pathological changes caused by the virus to the host, and thus melatonin seems to be an interesting nontoxic candidate for future studies on antagonists of viral infections [65].

Another important interaction involves BMAL1 and the HSV transcriptional machinery. BMAL1 is able to associate with the regulatory protein ICP0 [66]; it forms heterodimers with the histone acetyltransferase CLOCK and localizes at ND10 nuclear bodies. Viral proteins stabilize the heterodimer and enzymatically activate CLOCK, which associates with the transcriptional complex (ICP4, ICP27, ICP22, and TFIID), linking the replicative cycle of the virus to the molecular clockwork [67].

\subsection{Disruption of the Circadian Clock by Viruses}

Viral infection may also alter circadian gene expression as reported in different studies. Simian immunodeficiency virus (SIV) infection in monkeys caused changes in amplitude and values of body temperature and locomotor activity circadian rhythmicity after the acute retroviral syndrome stage. These changes were not linked to modifications detected in the acute febrile response triggered by virus inoculation. On the other hand, hypothalamic microglia infiltration and macrophage accumulation were shown to occur in animals sacrificed upon appearance of strong circadian anomalies, hinting at analogously significant physiological and psycho-cognitive consequences in human subjects with HIV infection [68]. Moreover, in vitro experiments performed in a cell line (Bel-7404-HBx) stably transfected with the hepatitis $B$ virus $X$ protein ( $\mathrm{HBx}$, involved in hepatocellular carcinogenesis) showed alterations in the mRNA expression levels for several core-clock genes, with upregulation of CLOCK, PER1, and PER2 and downregulation of BMAL1, PER3, CRY1, CRY2, and CKIE [69].

\subsection{The Biological Clock and Influenza Virus Infection}

A worldwide problem is represented by seasonal epidemics of influenza. Influenza is a disease with global impact that causes enormous morbidity and mortality on an annual basis. The severity of the infection depends on both the virus strain and a number of host factors, primarily age and the presence of comorbid conditions. The mortality and usage of healthcare resources associated with influenza is focused in the elderly and in those with a coexisting disease such as chronic obstructive pulmonary disease (COPD). In patients with COPD, the morbidity and mortality caused by an influenza virus infection are considerably greater.

In a COPD/emphysema mouse model, influenza A virus (IAV) infection reworked lung clock gene expression and decreased the amplitude in the rhythms of locomotor activity. This effect was more prominent in C57BL/6 $\mathrm{J}$ mice that were chronically exposed to cigarette smoke and was accompanied by decreased body weight and augmented mortality; likewise, Bmal1 knockout mice infected with IAV showed amplified lung inflammatory and pro-fibrotic responses.

Furthermore, the time of day of virus infection crucially impacts the outcome of IAV and this effect is observed under different types of light-dark cycles (12-h light/12-h darkness versus constant 
darkness), as well as in genetic circadian disruption models. The time of infection impacted late-viral clearance and IAV survival in Bmal1 flfl Ercre+ mice, and this time-of-day observed variation was abolished in Bmal1 ${ }^{-/}$mice. The rhythmic fluctuation of IAV-dependent effects was driven by inflammatory changes in the lung favouring better survival and related to a time point with high proportion of natural killer cells and of natural killer T lymphocytes and small percentages of inflammatory monocytes [70]. Accordingly, experiments performed in mice with targeted Bmal1 deletion in pulmonary airway epithelial cells (AECs), cellular elements that vitally shape the host/environment boundary, induced alterations in neutrophil infiltration, biomechanical function, and responses to influenza infection in the lungs. Analysis of the 24-h time-resolved RNA sequencing performed on laser-captured AECs indicates that extensive transcriptomic changes in circadian enriched pathways are linked to lipid metabolism, xenobiotic detoxification, extracellular matrix, and chemokine signalling [71].

The Bmal1 knockout findings suggest that proper functioning of the molecular clockwork is necessary for the immune response towards viral infections and the subsequent disease [72].

\subsection{Epigenetic Mechanisms Underlying the Interaction Between Viral Infection and the Circadian Clock Machinery}

Epigenetic regulatory mechanism, which includes DNA methylation and histone posttranslational modifications (PTM), leads to chromatin remodelling and regulated gene expression. Chromatin remodelling represents a critical process through which inputs, such as light or food, are transduced by the cell to generate permissive and silencing histone modifications to influence gene transcription and ultimately signalling pathway activity. CLOCK-BMAL1-dependent activation of clock-controlled genes is connected to circadian changes in histone PTM at their own promoters. Numerous chromatin remodelers, such as the deacetylases Sirtuin 1 (SIRT1, a NAD+-dependent histone deacetylase) and histone deacetylase 3 (HDAC3), are recruited to the promoter region of the clock-controlled genes in a circadian manner [34,73]. Importantly, the core element of the clockwork machinery, the transcription factor CLOCK, displays histone acetyltransferase activity as well. In the absence of these chromatin modifiers, the rhythmic expression of the clock-controlled genes is abrogated [73]. One of the most common epigenetic modifications is the methylation of DNA (addition of a methyl group to the cytosine residue in CPG dinucleotides mediated by the family of DNA methyltransferase enzymes DNMT1, DNMT3a, and DNMT3b). Overall DNA methylation with focal hypermethylation on the promoter of tumour suppressor genes, causing transcriptional silencing, is a mechanism of carcinogenesis [74-76]. These epigenetic mechanisms are critical for the functioning of the biological clock [73] and are disrupted by viral infection [74-76].

Previous studies report the existence of an interplay between the molecular clockwork, epigenetic modifications, and hepatitis $C$ virus $(\mathrm{HCV})$ in the liver, which affects $\sim 3 \%$ of the population worldwide. Infection with HCV is considered one of the main risk factors for hepatocellular carcinoma (HCC) [77]. $\mathrm{HCV}$ is clustered into six main genotypes (in turn divided into various subtypes) [78]. Abundant evidence has demonstrated that $\mathrm{HCV}$-related pathogenesis and its impact on liver disease is dependent on the genotype and that genetic and epigenetic mechanisms underlay viral interaction with cell processes and the molecular clockwork [79].

In the in vitro model of Huh-7 cells transfected with HCV core protein of different genotypes (1b, 2a, 3a, 4h, and 5a) [80], cellular DNMT1 and DNMT3b protein levels were increased in genotype $1 \mathrm{~b}$ or $3 \mathrm{a} \mathrm{HCV}$ core-expressing cells as compared to control cells [75]. Changes in the balance of DNA methylation mediated by DNMTs has been directly linked to HCV-dependent increase in hepatocarcinogenesis and in particular in the onset of hepatocellular carcinoma (HCC), hallmarked by global DNA hypomethylation and local hypermethylation on the promoter of tumour suppressor genes [74]. A recent meta-analysis showed that reduced E-cadherin (CDH1) expression is a predictor of poor prognosis in HCC patients [81]. CDH1 promoter is massively hypermethylated in genotype 1b HCV core protein-positive Huh-7 cells, in turn leading to reduced levels of CDH1 protein and increased levels of SIRT1 [76]. HCV-dependent alterations in SIRT1 function/activity have been shown 
by several studies performed in different cellular models [82-86]. In turn, SIRT1 is a well-established regulator of the circadian oscillation of clock-controlled genes in the liver, controlling fat metabolism, cell proliferation, and regeneration $[87,88]$. HCV has been shown to affect directly the circadian clock machinery. In Huh-7 cells expressing the HCV core protein genotype $1 \mathrm{~b}$, but not $3 \mathrm{a}$, protein levels of PER2 and CRY2 were found decreased [79]. Reciprocally, overexpression of PER2 led to a consistent decrease in the levels of HCV RNA undergoing replication [79]. Furthermore, in liver biopsies from HCV genotype 1b-infected patients, PER2 was almost exclusively localized to the nucleus, which is suggestive of an auto-inhibitory transcriptional feedback loop [79]. More recently, it was shown that the core-clock components BMAL1 and REV-ERB $\alpha$ act upon more steps in the HCV life cycle, including the entry of viral particles into hepatocytes and the replication of the viral RNA [89]. In fact, pharmacological activation of REV-ERB inhibited HCV entry, and genetic knockout of Bmal1 or overexpression/pharmacological activation of REV-ERB was able to counteract HCV replication by modulating the circadian expression of the liver-specific microRNA miR-122 with consequent derangements of signalling pathways involved in lipid metabolism [89]. A better understanding of circadian modulation of $\mathrm{HCV}$ life cycle and dynamic/rhythmic patterns of host-hosted interplay might lead to increased efficacy of therapies for HCV infection-related diseases.

\section{Conclusions}

Infectious agents exploit infected organisms in order to survive, multiply, settle, and eventually spoil. While some infections may remain asymptomatic or scarcely manifest, others are treatment resistant and have a grim prognosis. The immune system efficiently shields the body against infectious agents but eventually may fail, with harsh outcomes for the infected organism. Viruses are intracellular parasites hinging on the host cellular structures and cellular processes to replicate, survive, and disseminate. The biological clock drives circadian rhythmicity of cellular processes and immune functions, thus shaping the host response to viral infections and affecting the patterns of host-pathogen interaction [90]. Similarly to other infectious diseases, viral infections impact the circadian clock circuitry of the infected organism that, in turn, interacts with the molecular components of the infecting pathogens, pointing to a role of timing in this complex interplay and to a possible advantage of applying chrono-modulated antiviral therapeutic strategies. The contemporary chronotherapy employed or proposed in metabolic, immune, and neoplastic diseases could better address the outline of host-pathogen interaction, advancing the efficacy of antiviral therapy and improving the outcome of treatment of viral infections.

Even though much has been investigated in the circadian clock/immune system field in recent years, several open and outstanding questions remain to be addressed. Are different branches of the immune system differentially regulated by circadian rhythms? If autonomous ticking is dampened in peripheral tissues, do peripheral immune cells alter their rhythms/responses relative to immune cells in the thymus and lymph nodes? Do responses to vaccines that need boosters show different time-dependent patterns? Would different adjuvants boost vaccine responses in a time-of-day-dependent manner? Does deregulation of circadian rhythms correlate with reactivation of viruses known to cause latent infections (herpes simplex virus, varicella zoster virus, Epstein-Barr virus, human cytomegalovirus, human herpesvirus 6, human herpesvirus 7, Kaposi's sarcoma-associated herpesvirus, JC virus, BK virus, parvovirus, and adenovirus)? Do hibernating animal species mount different antiviral responses during hibernation? These are extremely interesting topics for future research, and the answers to the questions above will help pave new directions in the study of circadian-immune network interactions in the context of viral infections.

Author Contributions: Conceptualization, G.M.; writing-original draft preparation, G.M., M.V., and A.R.; writing-review and editing, G.M., A.C., M.V., and A.R.; supervision, G.M. and A.R.; funding acquisition, G.M. and A.R. All authors have read and agreed to the published version of the manuscript.

Funding: This study was supported by the " $5 \times 1000$ " voluntary contribution and by a grant from the Italian Ministry of Health (Ricerca Corrente 2018, 2019) to G.M.; by grants from the European Social Fund and European 
Regional Development Fund-Project MAGNET (No. CZ.02.1.01/0.0/0.0/15_003/0000492) to M.V.; and by the German Federal Ministry of Education and Research (BMBF)—eBio-CIRSPLICE - FKZ031A316 grant and by the Dr. Rolf M. Schwiete Stiftung-09/2017 grant to A.R.

Acknowledgments: The authors acknowledge support from the German Research Foundation (DFG) and the Open Access Publication Fund of Charité-Universitätsmedizin Berlin.

Conflicts of Interest: The authors declare no conflict of interest. The funders had no role in the design of the study; in the collection, analyses, or interpretation of data; in the writing of the manuscript; or in the decision to publish the results.

\section{References}

1. Dunlap, J.C. Molecular bases for circadian clocks. Cell 1999, 96, 271-290. [CrossRef]

2. Lowrey, P.L.; Takahashi, J.S. Genetics of circadian rhythms in mammalian model organisms. Adv. Genet. 2011, 74, 175-230. [PubMed]

3. von Schantz, M. Phenotypic effects of genetic variability in human clock genes on circadian and sleep parameters. J. Genet. 2008, 87, 513-519. [CrossRef]

4. Gachon, F.; Nagoshi, E.; Brown, S.A.; Ripperger, J.; Schibler, U. The mammalian circadian timing system: From gene expression to physiology. Chromosoma 2004, 113, 103-112. [CrossRef]

5. Dardente, H.; Cermakian, N. Molecular circadian rhythms in central and peripheral clocks in mammals. Chronobiol. Int. 2007, 24, 195-213. [CrossRef] [PubMed]

6. Hastings, M.H.; Maywood, E.S.; Reddy, A.B. Two decades of circadian time. J. Neuroendocrinol. 2008, 20, 812-819. [CrossRef] [PubMed]

7. Damiola, F.; Le Minh, N.; Preitner, N.; Kornmann, B.; Fleury-Olela, F.; Schibler, U. Restricted feeding uncouples circadian oscillators in peripheral tissues from the central pacemaker in the suprachiasmatic nucleus. Genes Dev. 2000, 14, 2950-2961. [CrossRef] [PubMed]

8. Rajaratnam, S.M.; Arendt, J. Health in a 24-h society. Lancet. 2001, 358, 999-1005. [CrossRef]

9. Stokkan, K.A.; Yamazaki, S.; Tei, H.; Sakaki, Y.; Menaker, M. Entrainment of the circadian clock in the liver by feeding. Science 2001, 291, 490-493. [CrossRef]

10. Izumo, M.; Johnson, C.H.; Yamazaki, S. Circadian gene expression in mammalian fibroblasts revealed by real-time luminescence reporting: Temperature compensation and damping. Proc. Natl. Acad. Sci. USA 2003, 100, 16089-16094. [CrossRef]

11. Tsuchiya, Y.; Akashi, M.; Nishida, E. Temperature compensation and temperature resetting of circadian rhythms in mammalian cultured fibroblasts. Genes Cells 2003, 8, 713-720. [CrossRef]

12. Abrahamson, E.E.; Moore, R.Y. Suprachiasmatic nucleus in the mouse: Retinal innervation, intrinsic organization and efferent projections. Brain Res. 2001, 916, 172-191. [CrossRef]

13. Stephan, F.K.; Zucker, I. Circadian rhythms in drinking behavior and locomotor activity of rats are eliminated by hypothalamic lesions. Proc. Natl. Acad. Sci. USA 1972, 69, 1583-1586. [CrossRef] [PubMed]

14. Moore, R.Y.; Eichler, V.B. Loss of a circadian adrenal corticosterone rhythm following suprachiasmatic lesions in the rat. Brain Res. 1972, 42, 201-206. [CrossRef]

15. Lehman, M.N.; Silver, R.; Gladstone, W.R.; Kahn, R.M.; Gibson, M.; Bittman, E.L. Circadian rhythmicity restored by neural transplant. Immunocytochemical characterization of the graft and its integration with the host brain. J. Neurosci. 1987, 7, 1626-1638. [CrossRef] [PubMed]

16. Ralph, M.R.; Foster, R.G.; Davis, F.C.; Menaker, M. Transplanted suprachiasmatic nucleus determines circadian period. Science 1990, 247, 975-978. [CrossRef] [PubMed]

17. Sujino, M.; Masumoto, K.H.; Yamaguchi, S.; van der Horst, G.T.; Okamura, H.; Inouye, S.T. Suprachiasmatic nucleus grafts restore circadian behavioral rhythms of genetically arrhythmic mice. Curr. Biol. 2003, 13, 664-668. [CrossRef]

18. Bjarnason, G.A.; Jordan, R.C.; Wood, P.A.; Li, Q.; Lincoln, D.W.; Sothern, R.B.; Hrushesky, W.J.; Ben-David, Y. Circadian expression of clock genes in human oral mucosa and skin: Association with specific cell-cycle phases. Am. J. Pathol. 2001, 158, 1793-1801. [CrossRef]

19. Yamazaki, S.; Numano, R.; Abe, M.; Hida, A.; Takahashi, R.; Ueda, M.; Block, G.D.; Sakaki, Y.; Menaker, M.; Tei, H. Resetting central and peripheral circadian oscillators in transgenic rats. Science 2000, 288, 682-685. [CrossRef] 
20. Yoo, S.H.; Yamazaki, S.; Lowrey, P.L.; Shimomura, K.; Ko, C.H.; Buhr, E.D.; Siepka, S.M.; Hong, H.K.; Oh, W.J.; Yoo, O.J.; et al. Period2: Luciferase real-time reporting of circadian dynamics reveals persistent circadian oscillations in mouse peripheral tissues. Proc. Natl. Acad. Sci. USA 2004, 101, 5339-5346. [CrossRef]

21. McNamara, P.; Seo, S.B.; Rudic, R.D.; Sehgal, A.; Chakravarti, D.; FitzGerald, G.A. Regulation of clock and mop4 by nuclear hormone receptors in the vasculature: A humoral mechanism to reset a peripheral clock. Cell 2001, 105, 877-889. [CrossRef]

22. King, D.P.; Takahashi, J.S. Molecular genetics of circadian rhythms in mammals. Annu. Rev. Neurosci. 2000, 23, 713-742. [CrossRef] [PubMed]

23. Antle, M.C.; Silver, R. Orchestrating time: Arrangements of the brain circadian clock. Trends Neurosci. 2005, 28, 145-151. [CrossRef] [PubMed]

24. Gooley, J.J.; Lu, J.; Chou, T.C.; Scammell, T.E.; Saper, C.B. Melanopsin in cells of origin of the retinohypothalamic tract. Nat. Neurosci. 2001, 4, 1165. [CrossRef] [PubMed]

25. Hannibal, J.; Hindersson, P.; Knudsen, S.M.; Georg, B.; Fahrenkrug, J. The photopigment melanopsin is exclusively present in pituitary adenylate cyclase-activating polypeptide-containing retinal ganglion cells of the retinohypothalamic tract. J. Neurosci. 2002, 22, RC191. [CrossRef] [PubMed]

26. Hannibal, J.; Hindersson, P.; Ostergaard, J.; Georg, B.; Heegaard, S.; Larsen, P.J.; Fahrenkrug, J. Melanopsin is expressed in pacap-containing retinal ganglion cells of the human retinohypothalamic tract. Invest. Ophthalmol. Vis. Sci. 2004, 45, 4202-4209. [CrossRef]

27. Hattar, S.; Liao, H.W.; Takao, M.; Berson, D.M.; Yau, K.W. Melanopsin-containing retinal ganglion cells: Architecture, projections, and intrinsic photosensitivity. Science 2002, 295, 1065-1070. [CrossRef]

28. Hannibal, J.; Moller, M.; Ottersen, O.P.; Fahrenkrug, J. Pacap and glutamate are co-stored in the retinohypothalamic tract. J. Comp. Neurol. 2000, 418, 147-155. [CrossRef]

29. Reppert, S.M.; Weaver, D.R. Coordination of circadian timing in mammals. Nature 2002, 418, $935-941$. [CrossRef]

30. Hastings, M.H.; Herzog, E.D. Clock genes, oscillators, and cellular networks in the suprachiasmatic nuclei. J. Biol. Rhythms 2004, 19, 400-413. [CrossRef]

31. Moore, R.Y.; Speh, J.C.; Leak, R.K. Suprachiasmatic nucleus organization. Cell Tissue Res. 2002, 309, 89-98. [CrossRef] [PubMed]

32. Moore, R.Y.; Speh, J.C. Gaba is the principal neurotransmitter of the circadian system. Neurosci. Lett. 1993, 150, 112-116. [CrossRef]

33. Hirota, T.; Fukada, Y. Resetting mechanism of central and peripheral circadian clocks in mammals. Zoolog. Sci. 2004, 21, 359-368. [CrossRef] [PubMed]

34. Takahashi, J.S. Transcriptional architecture of the mammalian circadian clock. Nat. Rev. Genet. 2017, 18, 164-179. [CrossRef] [PubMed]

35. Reddy, A.B.; O’Neill, J.S. Healthy clocks, healthy body, healthy mind. Trends Cell Biol. 2010, $20,36-44$. [CrossRef]

36. Staels, B. When the clock stops ticking, metabolic syndrome explodes. Nat. Med. 2006, 12, 54-55. [CrossRef]

37. Baraldo, M. The influence of circadian rhythms on the kinetics of drugs in humans. Expert Opin. Drug Metab. Toxicol. 2008, 4, 175-192. [CrossRef]

38. Levi, F. Therapeutic implications of circadian rhythms in cancer patients. Novartis Found. Symp. 2000, 227, 119-136.

39. Levi, F.; Schibler, U. Circadian rhythms: Mechanisms and therapeutic implications. Annu. Rev. Pharmacol. Toxicol. 2007, 47, 593-628. [CrossRef]

40. Scheiermann, C.; Kunisaki, Y.; Frenette, P.S. Circadian control of the immune system. Nat. Rev. Immunol. 2013, 13, 190-198. [CrossRef]

41. Fortier, E.E.; Rooney, J.; Dardente, H.; Hardy, M.P.; Labrecque, N.; Cermakian, N. Circadian variation of the response of t cells to antigen. J. Immunol. 2011, 187, 6291-6300. [CrossRef] [PubMed]

42. Gibbs, J.; Ince, L.; Matthews, L.; Mei, J.; Bell, T.; Yang, N.; Saer, B.; Begley, N.; Poolman, T.; Pariollaud, M.; et al. An epithelial circadian clock controls pulmonary inflammation and glucocorticoid action. Nat. Med. 2014, 20, 919-926. [CrossRef] [PubMed]

43. Nguyen, K.D.; Fentress, S.J.; Qiu, Y.; Yun, K.; Cox, J.S.; Chawla, A. Circadian gene bmal1 regulates diurnal oscillations of ly6c(hi) inflammatory monocytes. Science 2013, 341, 1483-1488. [CrossRef] [PubMed] 
44. Silver, A.C.; Arjona, A.; Walker, W.E.; Fikrig, E. The circadian clock controls toll-like receptor 9-mediated innate and adaptive immunity. Immunity 2012, 36, 251-261. [CrossRef]

45. Pick, R.; He, W.; Chen, C.S.; Scheiermann, C. Time-of-day-dependent trafficking and function of leukocyte subsets. Trends Immunol. 2019, 40, 524-537. [CrossRef]

46. Arjona, A.; Sarkar, D.K. Evidence supporting a circadian control of natural killer cell function. Brain Behav. Immun. 2006, 20, 469-476. [CrossRef]

47. Bollinger, T.; Leutz, A.; Leliavski, A.; Skrum, L.; Kovac, J.; Bonacina, L.; Benedict, C.; Lange, T.; Westermann, J.; Oster, H.; et al. Circadian clocks in mouse and human CD4+ T cells. PLoS ONE 2011, 6, e29801. [CrossRef]

48. Keller, M.; Mazuch, J.; Abraham, U.; Eom, G.D.; Herzog, E.D.; Volk, H.D.; Kramer, A.; Maier, B. A circadian clock in macrophages controls inflammatory immune responses. Proc. Natl. Acad. Sci. USA 2009, 106, 21407-21412. [CrossRef]

49. Froy, O.; Chapnik, N. Circadian oscillation of innate immunity components in mouse small intestine. Mol. Immunol. 2007, 44, 1954-1960. [CrossRef]

50. Druzd, D.; Matveeva, O.; Ince, L.; Harrison, U.; He, W.; Schmal, C.; Herzel, H.; Tsang, A.H.; Kawakami, N.; Leliavski, A.; et al. Lymphocyte circadian clocks control lymph node trafficking and adaptive immune responses. Immunity 2017, 46, 120-132. [CrossRef]

51. Ehlers, A.; Xie, W.; Agapov, E.; Brown, S.; Steinberg, D.; Tidwell, R.; Sajol, G.; Schutz, R.; Weaver, R.; Yu, H.; et al. Bmal1 links the circadian clock to viral airway pathology and asthma phenotypes. Mucosal. Immunol. 2018, 11, 97-111. [CrossRef] [PubMed]

52. Majumdar, T.; Dhar, J.; Patel, S.; Kondratov, R.; Barik, S. Circadian transcription factor bmal1 regulates innate immunity against select RNA viruses. Innate Immun. 2017, 23, 147-154. [CrossRef] [PubMed]

53. Phillips, A.C.; Gallagher, S.; Carroll, D.; Drayson, M. Preliminary evidence that morning vaccination is associated with an enhanced antibody response in men. Psychophysiology 2008, 45, 663-666. [CrossRef] [PubMed]

54. Long, J.E.; Drayson, M.T.; Taylor, A.E.; Toellner, K.M.; Lord, J.M.; Phillips, A.C. Morning vaccination enhances antibody response over afternoon vaccination: A cluster-randomised trial. Vaccine 2016, 34, 2679-2685. [CrossRef]

55. Kirby, T. Influenza vaccination in the morning improves response. Lancet. Respir. Med. 2016, 4, 435. [CrossRef]

56. Dowell, S.F. Seasonal variation in host susceptibility and cycles of certain infectious diseases. Emerg. Infect. Dis. 2001, 7, 369-374. [CrossRef]

57. Dopico, X.C.; Evangelou, M.; Ferreira, R.C.; Guo, H.; Pekalski, M.L.; Smyth, D.J.; Cooper, N.; Burren, O.S.; Fulford, A.J.; Hennig, B.J.; et al. Widespread seasonal gene expression reveals annual differences in human immunity and physiology. Nat. Commun. 2015, 6, 7000. [CrossRef]

58. Edgar, R.S.; Stangherlin, A.; Nagy, A.D.; Nicoll, M.P.; Efstathiou, S.; O’Neill, J.S.; Reddy, A.B. Cell autonomous regulation of herpes and influenza virus infection by the circadian clock. Proc. Natl. Acad. Sci. USA 2016, 113, 10085-10090. [CrossRef]

59. Matsuzawa, T.; Nakamura, Y.; Ogawa, Y.; Ishimaru, K.; Goshima, F.; Shimada, S.; Nakao, A.; Kawamura, T. Differential day-night outcome to HSV-2 cutaneous infection. J. Invest. Dermatol. 2018, 138, 233-236. [CrossRef]

60. Zhao, L.; Liu, M.; Ouyang, J.; Zhu, Z.; Geng, W.; Dong, J.; Xiong, Y.; Wang, S.; Zhang, X.; Qiao, Y.; et al. The Per-1 Short Isoform Inhibits de novo HIV-1 Transcription in Resting Cd4+ T-cells. Curr. HIV Res. 2018, 16, 384-395. [CrossRef]

61. Gatfield, D.; Le Martelot, G.; Vejnar, C.E.; Gerlach, D.; Schaad, O.; Fleury-Olela, F.; Ruskeepaa, A.L.; Oresic, M.; Esau, C.C.; Zdobnov, E.M.; et al. Integration of microRNA miR-122 in hepatic circadian gene expression. Genes Dev. 2009, 23, 1313-1326. [CrossRef] [PubMed]

62. Luna, J.M.; Scheel, T.K.; Danino, T.; Shaw, K.S.; Mele, A.; Fak, J.J.; Nishiuchi, E.; Takacs, C.N.; Catanese, M.T.; de Jong, Y.P.; et al. Hepatitis C virus RNA functionally sequesters miR-122. Cell 2015, 160, 1099-1110. [CrossRef] [PubMed]

63. Bonilla, E.; Valero-Fuenmayor, N.; Pons, H.; Chacin-Bonilla, L. Melatonin protects mice infected with venezuelan equine encephalomyelitis virus. Cell Mol. Life Sci. 1997, 53, 430-434. [CrossRef] [PubMed] 
64. Gitto, E.; Karbownik, M.; Reiter, R.J.; Tan, D.X.; Cuzzocrea, S.; Chiurazzi, P.; Cordaro, S.; Corona, G.; Trimarchi, G.; Barberi, I. Effects of melatonin treatment in septic newborns. Pediatr. Res. 2001, 50, 756-760. [CrossRef]

65. Tan, D.X.; Korkmaz, A.; Reiter, R.J.; Manchester, L.C. Ebola virus disease: Potential use of melatonin as a treatment. J. Pineal. Res. 2014, 57, 381-384. [CrossRef]

66. Kawaguchi, Y.; Tanaka, M.; Yokoymama, A.; Matsuda, G.; Kato, K.; Kagawa, H.; Hirai, K.; Roizman, B. Herpes simplex virus 1 alpha regulatory protein ICP0 functionally interacts with cellular transcription factor BMAL1. Proc. Natl. Acad. Sci. USA 2001, 98, 1877-1882. [CrossRef]

67. Kalamvoki, M.; Roizman, B. The Histone Acetyltransferase CLOCK is an Essential Component of the Herpes Simplex Virus 1 Transcriptome That Includes TFIID, ICP4, ICP27, and ICP22. J. Virol. 2011, 85, 9472-9477. [CrossRef]

68. Huitron-Resendiz, S.; Marcondes, M.C.; Flynn, C.T.; Lanigan, C.M.; Fox, H.S. Effects of simian immunodeficiency virus on the circadian rhythms of body temperature and gross locomotor activity. Proc. Natl. Acad. Sci. USA 2007, 104, 15138-15143. [CrossRef]

69. Yang, S.L.; Yu, C.; Jiang, J.X.; Liu, L.P.; Fang, X.; Wu, C. Hepatitis B virus X protein disrupts the balance of the expression of circadian rhythm genes in hepatocellular carcinoma. Oncol. Lett. 2014, 8, 2715-2720. [CrossRef]

70. Sengupta, S.; Tang, S.Y.; Devine, J.C.; Anderson, S.T.; Nayak, S.; Zhang, S.L.; Valenzuela, A.; Fisher, D.G.; Grant, G.R.; Lopez, C.B.; et al. Circadian control of lung inflammation in influenza infection. Nat. Commun. 2019, 10, 4107. [CrossRef]

71. Zhang, Z.; Hunter, L.; Wu, G.; Maidstone, R.; Mizoro, Y.; Vonslow, R.; Fife, M.; Hopwood, T.; Begley, N.; Saer, B.; et al. Genome-wide effect of pulmonary airway epithelial cell-specific bmal1 deletion. FASEB J. 2019, 33, 6226-6238. [CrossRef] [PubMed]

72. Sundar, I.K.; Ahmad, T.; Yao, H.; Hwang, J.W.; Gerloff, J.; Lawrence, B.P.; Sellix, M.T.; Rahman, I. Influenza A virus-dependent remodeling of pulmonary clock function in a mouse model of COPD. Sci. Rep. 2015, 4, 9927. [CrossRef] [PubMed]

73. Sahar, S.; Sassone-Corsi, P. The epigenetic language of circadian clocks. Handb. Exp. Pharmacol. 2013, $29-44$.

74. Jueliger, S.; Lyons, J.; Cannito, S.; Pata, I.; Pata, P.; Shkolnaya, M.; Lo Re, O.; Peyrou, M.; Villarroya, F.; Pazienza, V.; et al. Efficacy and epigenetic interactions of novel DNA hypomethylating agent guadecitabine (SGI-110) in preclinical models of hepatocellular carcinoma. Epigenetics 2016, 11, 709-720. [CrossRef] [PubMed]

75. Benegiamo, G.; Vinciguerra, M.; Mazzoccoli, G.; Piepoli, A.; Andriulli, A.; Pazienza, V. DNA methyltransferases 1 and $3 \mathrm{~b}$ expression in huh-7 cells expressing HCV core protein of different genotypes. Dig. Dis. Sci. 2012, 57, 1598-1603. [CrossRef] [PubMed]

76. Ripoli, M.; Barbano, R.; Balsamo, T.; Piccoli, C.; Brunetti, V.; Coco, M.; Mazzoccoli, G.; Vinciguerra, M.; Pazienza, V. Hypermethylated levels of e-cadherin promoter in huh-7 cells expressing the HCV core protein. Virus Res. 2011, 160, 74-81. [CrossRef]

77. El-Serag, H.B. Epidemiology of viral hepatitis and hepatocellular carcinoma. Gastroenterology 2012, 142, 1264.e1-1273.e1. [CrossRef]

78. Ripoli, M.; Pazienza, V. Impact of HCV genetic differences on pathobiology of disease. Expert Rev. Anti-Infect. Ther. 2011, 9, 747-759. [CrossRef]

79. Benegiamo, G.; Mazzoccoli, G.; Cappello, F.; Rappa, F.; Scibetta, N.; Oben, J.; Greco, A.; Williams, R.; Andriulli, A.; Vinciguerra, M.; et al. Mutual antagonism between circadian protein period 2 and hepatitis C virus replication in hepatocytes. PLoS ONE 2013, 8, e60527.

80. Pazienza, V.; Vinciguerra, M.; Andriulli, A.; Mangia, A. Hepatitis C virus core protein genotype 3a increases SOCS-7 expression through PPAR-\{gamma\} in Huh-7 cells. J. Gen. Virol. 2010, 91, 1678-1686. [CrossRef]

81. Chen, J.; Zhao, J.; Ma, R.; Lin, H.; Liang, X.; Cai, X. Prognostic Significance of E-Cadherin Expression in Hepatocellular Carcinoma: A Meta-Analysis. PLoS ONE 2014, 9, e103952. [CrossRef] [PubMed]

82. Jiang, L.; Gu, Y.; Ye, J.; Liu, F.; Zhao, Y.; Wang, C.; Xu, Y.; Cao, X.; Zhang, L.; Dong, W.; et al. Resveratrol prevents hepatic steatosis induced by hepatitis C virus core protein. Biotechnol. Lett. 2012, 34, 2205-2212. [CrossRef] [PubMed]

83. Sun, L.J.; Li, S.C.; Zhao, Y.H.; Yu, J.W.; Kang, P.; Yan, B.Z. Silent information regulator 1 inhibition induces lipid metabolism disorders of hepatocytes and enhances hepatitis C virus replication. Hepatol. Res. 2013, 43, 1343-1351. [CrossRef] [PubMed] 
84. Feng, S.; Li, M.; Zhang, J.; Liu, S.; Wang, Q.; Quan, M.; Zhang, M.; Cheng, J. Regulation of hepG2 cell apoptosis by hepatitis C virus (HCV) core protein via the sirt1-p53-bax pathway. Virus Genes 2015, 51, 338-346. [CrossRef]

85. Zhou, Y.; Li, G.Y.; Ren, J.P.; Wang, L.; Zhao, J.; Ning, S.B.; Zhang, Y.; Lian, J.Q.; Huang, C.X.; Jia, Z.S.; et al. Protection of $c d 4+t$ cells from hepatitis $C$ virus infection-associated senescence via deltanp63-mir-181a-sirt1 pathway. J. Leukoc. Biol. 2016, 100, 1201-1211. [CrossRef]

86. Sun, L.J.; Yu, J.W.; Shi, Y.G.; Zhang, X.Y.; Shu, M.N.; Chen, M.Y. Hepatitis C virus core protein induces dysfunction of liver sinusoidal endothelial cell by down-regulation of silent information regulator 1. J. Med. Virol. 2018, 90, 926-935. [CrossRef]

87. Bellet, M.M.; Masri, S.; Astarita, G.; Sassone-Corsi, P.; Della Fazia, M.A.; Servillo, G. Histone deacetylase sirt1 controls proliferation, circadian rhythm, and lipid metabolism during liver regeneration in mice. J. Biol. Chem. 2016, 291, 23318-23329. [CrossRef]

88. Sato, S.; Solanas, G.; Peixoto, F.O.; Bee, L.; Symeonidi, A.; Schmidt, M.S.; Brenner, C.; Masri, S.; Benitah, S.A.; Sassone-Corsi, P. Circadian Reprogramming in the Liver Identifies Metabolic Pathways of Aging. Cell 2017, 170, 664e11-677e11. [CrossRef]

89. Zhuang, X.; Magri, A.; Hill, M.; Lai, A.G.; Kumar, A.; Rambhatla, S.B.; Donald, C.L.; Lopez-Clavijo, A.F.; Rudge, S.; Pinnick, K.; et al. The circadian clock components BMAL1 and REV-ERB $\alpha$ regulate flavivirus replication. Nat. Commun. 2019, 10, 377. [CrossRef]

90. Zhuang, X.; Rambhatla, S.B.; Lai, A.G.; McKeating, J.A. Interplay between circadian clock and viral infection. J. Mol. Med. (Berl) 2017, 95, 1283-1289. [CrossRef]

(C) 2020 by the authors. Licensee MDPI, Basel, Switzerland. This article is an open access article distributed under the terms and conditions of the Creative Commons Attribution (CC BY) license (http://creativecommons.org/licenses/by/4.0/). 